\title{
Le noir et le rouge, Itinéraire social, culturel et politique d'un prêtre patriote (1736-1799).
}

\section{Serge Bianchi}

\section{(2) OpenEdition \\ 1 Journals}

\section{Édition électronique}

URL : https://journals.openedition.org/ahrf/1151

DOI : 10.4000/ahrf.1151

ISSN : 1952-403X

Éditeur :

Armand Colin, Société des études robespierristes

\section{Édition imprimée}

Date de publication : 1 septembre 2001

Pagination : 140-142

ISSN : 0003-4436

\section{Référence électronique}

Serge Bianchi, « Le noir et le rouge, Itinéraire social, culturel et politique d'un prêtre patriote

(1736-1799). », Annales historiques de la Révolution française [En ligne], 325 | juillet-septembre 2001, mis en ligne le 22 avril 2004, consulté le 24 avril 2022. URL : http://journals.openedition.org/ahrf/1151

DOl : https://doi.org/10.4000/ahrf.1151

Ce document a été généré automatiquement le 24 avril 2022.

Tous droits réservés 


\title{
Le noir et le rouge, Itinéraire social, culturel et politique d'un prêtre patriote (1736-1799).
}

\author{
Serge Bianchi
}

Philippe Bourdin, Le noir et le rouge, Itinéraire social, culturel et politique d'un prêtre patriote (1736-1799), Presses universitaires Blaise Pascal, 2000, 524 pages. 